
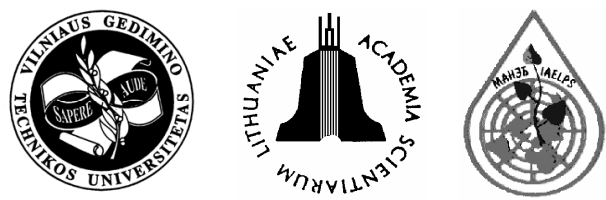

\title{
ORGANIC WASTE PRODUCTS IN AGRICULTURE - MONITORING THE WASTE CONSTITUENTS PHTHALATE ESTERS IN SOIL-CROP SYSTEM BY GAS CHROMATOGRAPHY AND ION TRAP TANDEM MASS SPECTROMETRY
}

\author{
Frank Laturnus* and Christian Grøn ${ }^{1}$ \\ Plant Biology Department, RISØ National Laboratory, 4000 Roskilde, Denmark \\ *Centre for Climate Science and Policy Research, Linköping university, 60174 Norrköping, Sweden, and \\ Hanse Institute for Advanced Studies, 27553 Delmenhorst, Germany. E-mail: frank.laturnus@tema.liu.se \\ ${ }^{1}$ DHI Water*Environment*Health, Agern Allé 5, 2970 Hørsholm, Denmark. E-mail: chg@dhi.dk
}

Submitted 15 May 2007; accepted 24 Sept. 2007

\begin{abstract}
A method is described for monitoring phthalate esters in organic waste products, agricultural soil and crops. Solvent extraction, Ultra Turrax homogenisation and sonification were used to isolate the compounds from the sample matrices. Solid phase extraction was applied for purification, and gas chromatography with tandem mass spectrometry for identification. With the method, six phthalate esters were determined in different matrices. The detection limits were in the range of 1 to $10 \mu \mathrm{g} \mathrm{kg}-1$ wet weight, except for DEHP, which had a detection limit approaching $100 \mu \mathrm{g} \mathrm{kg}^{-1}$ wet weight. Repeatabilities were from 5 to $20 \%$ relative standard deviation. Recoveries were from 6 to $100 \%$, depending on the compound analysed. However, except for the polar phthalates DMP and DEP, the recoveries were above $70 \%$. The method feasibility was demonstrated in an investigation of the occurrence of phthalate esters in barley, rape, carrots, agricultural soil, aerobic and anaerobic sludge, household compost and pig manure.
\end{abstract}

Keywords: phthalate esters, sewage sludge, tandem mass spectrometry, ion trap, agriculture.

\section{Introduction}

In modern society, the intensive use of industrial organic chemicals leads to a high input of these compounds into the terrestrial and aquatic ecosystems. Due to human health concerns associated with some of these chemicals, their presence in agricultural ecosystems is of particular concern, as they can be transferred to humans by food crops after plant-uptake or leaching to groundwater. Introduction of organic contaminants into the agricultural system can be through atmospheric deposition, pesticide application, wastewater reuse (irrigation) and fertilisation with organic waste products, such as manure, organic industrial waste and organic household waste [1]. One group of compounds of special interest is the one of phthalate esters (Table 1) [2].

These compounds are widely used in industry mainly as the most important plasticizers in flexible polyvinylchloride [3]. They are an interesting class of compounds from the environmental point of view due to their moderate persistence and the large world-wide production of around 4 million tons $\mathrm{yr}^{-1}$ [4]. Some of them are suspected to be carcinogenic, some have been associated with estrogenic effects and they have been listed as priority pollutants by the U.S. Environmental Protection Agency [5].

Phthalate esters, especially bis-[2-ethylhexy] phthalate (DEHP), are selected as priority pollutants due to their ubiquitous occurrence in the environment [6]. Therefore, analysis of phthalate esters requires beside adequate isolation, purification and analytical techniques thorough cleaning steps to minimise contamination of the equipment and reduce blank levels [7-9]. Analysis of phthalate esters in different matrices have frequently been reported in literature. However, data about phthalate esters in plant material are scarce. The technique used for the isolation of phthalate esters depends on the sample matrices investigated. Common methods are solvent extraction of water samples [7, 9-11], soxhlet [12-15], or ultrasonic treatment for soil matrices [16]. A new method yet so far not described in literature for the analysis of phthalate esters may be the extraction of soil with super critical fluids (SFE) [17]. From plant matrices, simple solvent extraction is insufficient for the isolation of phthalate esters. Additional steps like ultrasonic treatment $[10,18]$ or homogenisation by Ultra Turrax [14] are required to obtain sufficient recoveries. For minimisation of interferences common ways to clean the extracts are purification by solid phase extraction (SPE). Either by retaining the phthalate esters on the solid phase (reversed phase extraction) and subsequent elution of the phthalate esters with appropriate solvents [7], or by removing the polar compounds from the extract (normal phase extraction) $[9,11,19]$. The final concentration of the extracts is done by evaporation of the solvent with ultraclean nitrogen to a certain volume [19], or to dryness followed by re-dissolving in a suitable solvent $[9,20]$. 
Table 1. Mass spectrometric data of different phthalate esters

$\mathrm{O}$

$\begin{array}{lll}\mathrm{C} & & \mathrm{R}_{1} \\ & \mathrm{O} & \\ & \mathrm{O} & \\ \mathrm{C} & & \mathrm{R}_{2} \\ \mathrm{O} & & \end{array}$

\begin{tabular}{c|c|c|c|c|c}
\hline $\begin{array}{c}\text { Phthalate } \\
\text { ester }\end{array}$ & Acronym & $\mathrm{R}_{1} / \mathrm{R}_{2}$ & $\begin{array}{c}\text { Molecular } \\
\text { mass } \\
{[\mathrm{g}]}\end{array}$ & $\begin{array}{c}\text { Mass spectrometric } \\
\text { method }\end{array}$ & $\begin{array}{c}\mathrm{m} / \text { z of selected mother ion fragments } \\
\text { and corresponding daughter ion } \\
\text { fragments }\end{array}$ \\
\hline dimethyl- & DMP & $\mathrm{R}_{1} / \mathrm{R}_{2}=\mathrm{CH}_{3}$ & 194.19 & $\mathrm{SIM}^{1)}, \mathrm{CID}^{2)} 0 \mathrm{~V}$ & 163 \\
\hline diethyl- & DEP & $\mathrm{R}_{1} / \mathrm{R}_{2}=\mathrm{C}_{2} \mathrm{H}_{5}$ & 222.20 & MS-MS ${ }^{3)}, \mathrm{CID} 46 \mathrm{~V}$ & $149 \rightarrow 121+65$ \\
\hline di-n-butyl- & DBP & $\mathrm{R}_{1} / \mathrm{R}_{2}=\mathrm{C}_{2} \mathrm{H}_{9}$ & 278.35 & MS-MS, CID 46V & $149 \rightarrow 121+65$ \\
\hline benzylbutyl- & BBP & $\begin{array}{c}\mathrm{R}_{1}=\mathrm{C}_{7} \mathrm{H}_{7} \\
\mathrm{R}_{2}=\mathrm{C}_{4} \mathrm{H}_{9}\end{array}$ & 312.37 & MS-MS, CID 46V & $149 \rightarrow 121+65$ \\
\hline $\begin{array}{c}\text { bis [2- } \\
\text { ethylhexyl]- }\end{array}$ & DEHP & $\mathrm{R}_{1} / \mathrm{R}_{2}=\mathrm{C}_{8} \mathrm{H}_{17}$ & 390.59 & MS-MS, CID 46V & $149 \rightarrow 121+65$ \\
\hline dioctyl- & DOP & $\mathrm{R}_{1} / \mathrm{R}_{2}=\mathrm{C}_{8} \mathrm{H}_{17}$ & 390.59 & MS-MS, CID 46V & $149 \rightarrow 121+65$ \\
\hline
\end{tabular}

${ }^{1)}$ single ion monitoring ${ }^{2)}$ collusion induced dissociation ${ }^{3)}$ tandem mass spectrometry

As the disposal of organic waste products becomes more and more a problem in modern society, the application of organic waste in agriculture may be an efficient and low-cost method for disposal. To ensure a safe food production any possible risks resulting from the application of organic waste in agriculture have to be investigated. To do so sensitive, multiple-applicable, fast and reliable analytical techniques are necessary. In this study, a method is described to analyse six different phthalate esters simultaneously in crops and organic waste samples. The results of the investigation of barley, rape, carrots, agricultural soil, pig manure, household compost, aerobic sludge and anaerobic sludge are presented.

\section{Material and methods}

Glassware. All glassware first was cleaned in an ordinary dishwasher and dried in a drying-oven. Then, the glassware was heated for 1 hour at $500{ }^{\circ} \mathrm{C}$ and cooled down to room temperature under a constant flow of air pre-cleaned with activated coal. All glassware was closed with or wrapped in aluminum foil. The decontamination was repeated once a week. The use of high temperature is an efficient way to remove organic contaminants from glassware. However, a high temperature can cause an activation of the glass surface, which may lead to adsorption of the phthalate esters on the glass surface [7]. Therefore, all equipment was flushed with hexane prior to use.

Chemicals. All solvents were of p.a. grade. Extraction solvents were checked prior to use for phthalate ester contamination by evaporating $10 \mathrm{ml}$ solvent down to $0.5 \mathrm{ml}$ and analysing the extract. Sodium sulphate was of p.a. grade and pre-cleaned for 1 hour at $500{ }^{\circ} \mathrm{C}$.

Soils and plants. The plants were grown in soil mixtures composed of sieved sandy soil with pig manure obtained from a farm close to Copenhagen, household compost and sewage sludge products of mixed industrial and domestic origin from a wastewater treatment plant close to Copenhagen. For further details refer to [21]. Carrots (Daucus carota L.), barley (Hordeum vulgare L. w. Apex) and rape (Brassica napus L.) were cultivated to young green plants (barley 3 weeks, rape 4 weeks) and to maturity (carrots 3 months) in the controlled environment of a greenhouse. Barley and rape were grown in 3.21 glass pots. Carrots were grown in 201 stainless steel pots. Watering was done to maintain $60-75 \%$ of the water holding capacity. The day lengths were 16 hours at photon fluxes between 100 to $155 \mu \mathrm{mol} \mathrm{m} \mathrm{sec}^{-1}$. The temperature was maintained at $12-18{ }^{\circ} \mathrm{C}$. For carrots however, an increase up to $25^{\circ} \mathrm{C}$ was measured due to high sun radiation during parts of the growth period. The air humidity varied between 35 to $40 \%$ (for carrots 10 to $33 \%$ during parts of the growth period). The plants were protected against dry deposition with a glass dust cover.

Sample preparation. Pre-treatment for homogenization and drying of the soil and waste product samples was done by mixing with sodium sulphate (1:1) and grinding in an automatic agat mortar. The homogenised samples were stored at $-20{ }^{\circ} \mathrm{C}$ until analysis. Harvested plants were cut into small pieces (0.5 to $1 \mathrm{~cm}$ length) and stored at $-20{ }^{\circ} \mathrm{C}$ until analysis.

Extraction. The overall analytical procedure is given in Fig 1.

For plants, $3 \mathrm{~g}$ of sample material was weighted into a $120 \mathrm{ml}$ centrifuge glass and $10 \mathrm{ml}$ of acetone was added. The plant/solvent mixture was homogenised with an Ultra Turrax T25 at $9500 \mathrm{rpm}$ for $1 \mathrm{~min}$. Then $10 \mathrm{ml}$ of hexane was added followed by additional $2 \mathrm{~min}$. of Ultra Turrax treatment. After centrifugation $(3500 \mathrm{rpm}$ for 3 min., Sigma 4-15 centrifuge), the residue was washed with $10 \mathrm{ml}$ of hexane, homogenised again with an Ultra Turrax (9500 rpm for $1 \mathrm{~min}$.) and centrifuged (3500 rpm for $3 \mathrm{~min}$.). This procedure was repeated once. The combined extracts were dried with sodium sulphate, 


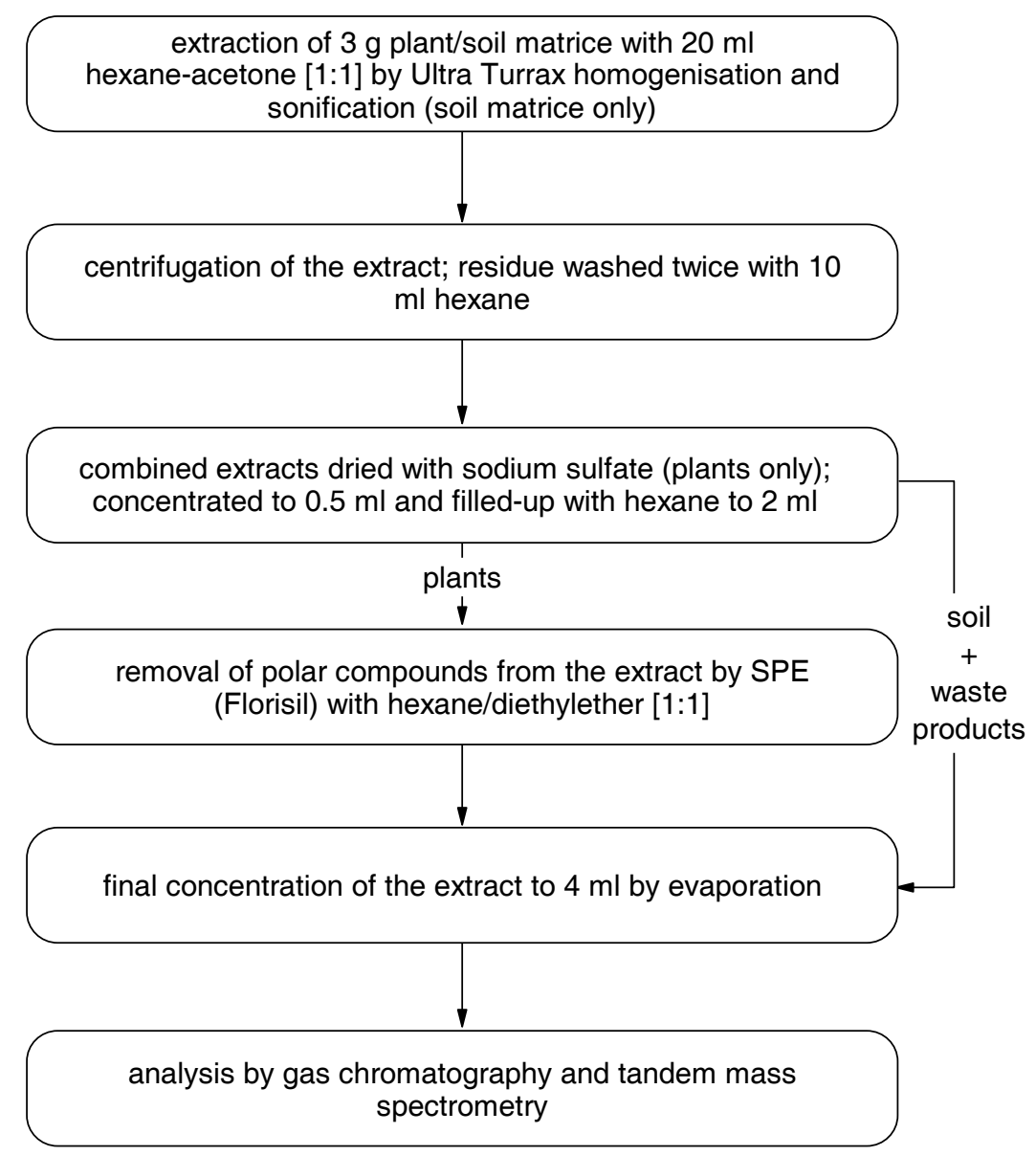

Fig 1. Work-up diagram for the determination of phthalate esters from soil, organic waste and crops

concentrated to $0.5 \mathrm{ml}$ by evaporation under a stream of nitrogen (pre-cleaned over an OMI-2 gas cleaner, Supelco), and filled-up to $2 \mathrm{ml}$ with hexane. To remove the polar compounds from the extract, a clean-up was done by solid phase extraction. A small glass column $(6 \mathrm{ml})$ was packed with $1.5 \mathrm{~g}$ Florisil fixed between two polytetrafluoroethane (PTFE) frits. The SPE-column was washed with $10 \mathrm{ml}$ hexane/acetone $(1: 1)$ and activated with $10 \mathrm{ml}$ hexane/diethyl ether (1:1). After adding the extract, the non-polar compounds were eluted with $12 \mathrm{ml}$ hexane/diethyl ether, and the extract was concentrated by evaporation with pre-cleaned nitrogen to a final volume of $2 \mathrm{ml}$. The extract was stored in vials at $-20{ }^{\circ} \mathrm{C}$ until gas chromatographic analysis.

For soil and waste products, 1 to $3 \mathrm{~g}$ homogenised sample was extracted with $20 \mathrm{ml}$ acetone/hexane (1:1) and $3 \mathrm{~min}$. of Ultra Turrax treatment followed by $5 \mathrm{~min}$ sonification. After centrifugation (3 min. at $3500 \mathrm{rpm}$ ), the residue was washed with $10 \mathrm{ml}$ of hexane, homogenised again with Ultra Turrax (9500 rpm for $1 \mathrm{~min}$.) and $1 \mathrm{~min}$. of sonification, and, finally, centrifuged (3500 rpm for $3 \mathrm{~min}$.). This procedure was repeated once. The combined extracts were concentrated to $0.5 \mathrm{ml}$ by pre-cleaned nitrogen and filled to $2 \mathrm{ml}$ with hexane. To remove residues carried over from the soil extraction, the final extract was centrifuged (3500 rpm for $3 \mathrm{~min}$.), and the residue was washed with $1.5 \mathrm{ml}$ of hexane, sonificated (1 min.) and centrifuged. The combined extracts were adjusted to $2 \mathrm{ml}$ final volume and stored in vials at $20^{\circ} \mathrm{C}$ until gas chromatographic analysis.

Gas chromatographic analysis. Analysis and identification of the phthalate esters was done on a Varian STAR 3400 gas chromatograph equipped with an Varian Saturn III ion trap mass spectrometer with direct capillary interface and a Varian $8200 \mathrm{cx}$ autosampler. The injector was held at $250{ }^{\circ} \mathrm{C}$ and injections were done in splitless mode. For separation, an XTI-5 capillary column was used (Restek, $1=30 \mathrm{~m}, \mathrm{ID}=0.25 \mathrm{~mm}, \mathrm{~d}=0.25 \mu \mathrm{m}$ ) (see Fig 2 for a chromatogram).

The temperature programme was $60^{\circ} \mathrm{C}$ for $5 \mathrm{~min}$., $20{ }^{\circ} \mathrm{C} \mathrm{min} .^{-1}$ to $340{ }^{\circ} \mathrm{C}$, and kept at $340{ }^{\circ} \mathrm{C}$ for $3 \mathrm{~min}$. The transfer line was kept at $280^{\circ} \mathrm{C}$. For detection and identification, the ion trap-tandem mass spectrometer was used in the non-resonance mode with collusion induced dissociation (CID). Excitation voltage was set to $46 \mathrm{~V}$, and the excitation radio frequency (RF) storage level set to $\mathrm{m} / \mathrm{z}$ 149. Additional parameters: manifold temperature $200^{\circ} \mathrm{C}$, $\mathrm{A} / \mathrm{M}$ amplitude voltage $3.2 \mathrm{~V}$, scan rate $1000 \mathrm{msec}$, isolation window $3.0 \mathrm{~m} / \mathrm{z}$, excitation time $25 \mathrm{msec}$, target value 5000 , CID resonance wave $20 \mathrm{msec}$. Data on the parameters for analysing phthalate esters are given in Table 2.

Quantification and quality control. For quantification, dilution of the pure phthalate esters in isooctane were prepared and used for multi-point calibration curves. As controls, in each analytical series, one blank sample (procedure without a soil or plant sample) and one spiked 


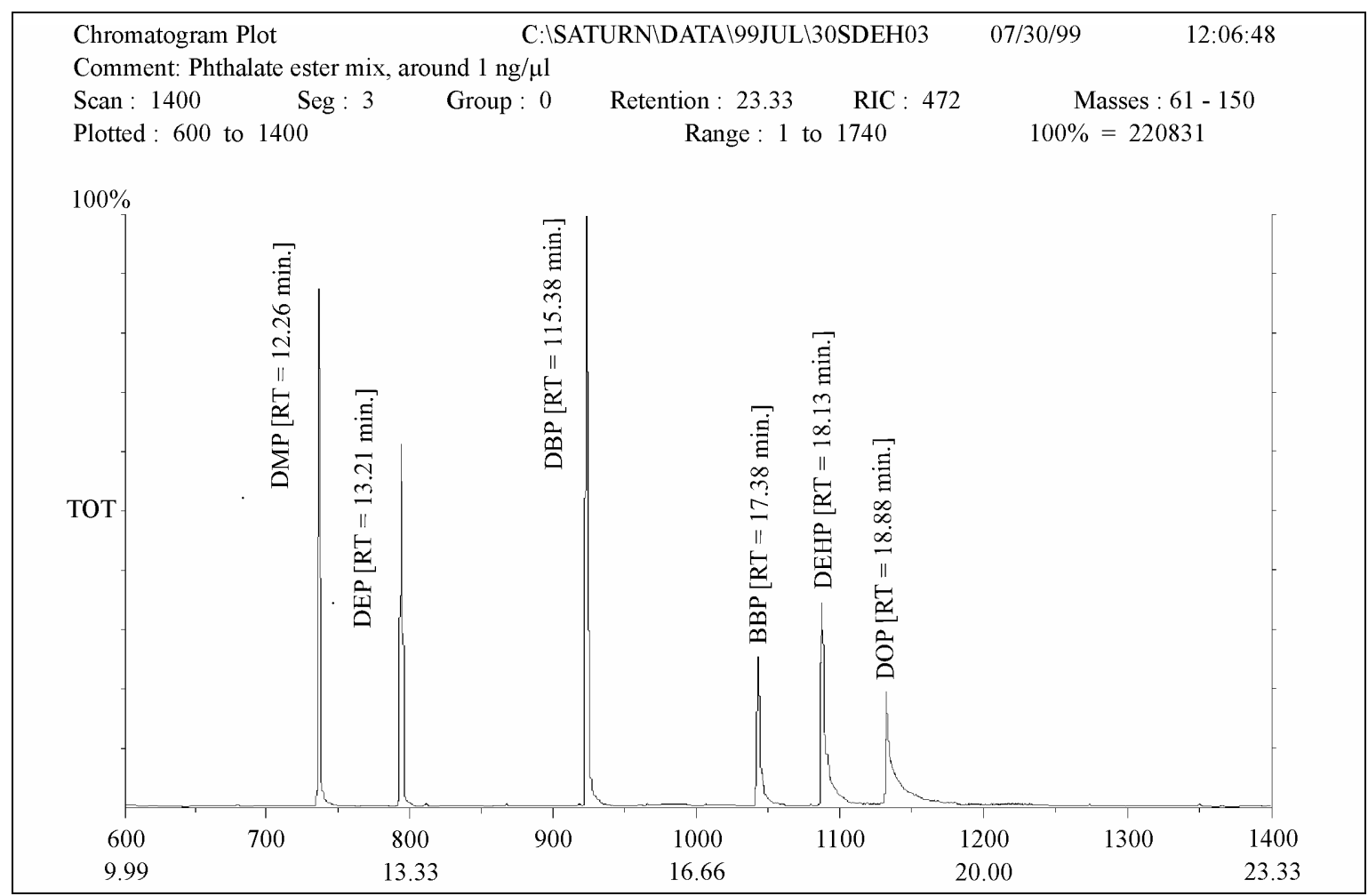

Fig 2. Total ion chromatogram of the phthalate esters investigated. RT = retention time in minutes

Table 2. Instrumental detection limits, method blanks and recoveries of phthalate esters for different sample matrices. Values in percent except detection limits and method blanks. In brackets the relative standard variation $\mathrm{s}_{\mathrm{n}-1}$ is given

\begin{tabular}{|c|c|c|c|c|c|c|c|}
\hline & DMP & DEP & DBP & BBP & DEHP & DOP & \\
\hline instrumental detection limit (plants) ${ }^{1 / 3)}$ & $<0.63^{4)}$ & 3.81 & 9.53 & $<1.58^{4)}$ & 61.9 & $<3.43^{4)}$ & $\mathrm{n}=4$ \\
\hline instrumental detection limit (soil) $^{1) 3)}$ & $<0.63^{4)}$ & 3.26 & 3.27 & $<1.58^{4)}$ & 92.3 & $<3.43^{4)}$ & $\mathrm{n}=3$ \\
\hline method detection limit (plants) ${ }^{2)}$ & 0 & $4.2 \pm 0.8$ & $9.3 \pm 2.1$ & 0 & $114.2 \pm 13.6$ & 0 & $\mathrm{n}=4$ \\
\hline method detection limit (soil) ${ }^{2)}$ & 0 & $4.3 \pm 0.6$ & $9.3 \pm 2.1$ & 0 & $43.0 \pm 17.2$ & 0 & $\mathrm{n}=3$ \\
\hline $\begin{array}{c}\text { recovery } \\
\text { no matrix } \\
\text { (soil method) }\end{array}$ & $78(2)$ & $85(2)$ & $81(8)$ & $100(10)$ & $89(4)$ & $77(4)$ & $\mathrm{n}=3$ \\
\hline $\begin{array}{c}\text { recovery } \\
\text { no matrix } \\
\text { (plant method) }\end{array}$ & $65(6)$ & $77(6)$ & $92(9)$ & $83(3)$ & $85(3)$ & $91(6)$ & $\mathrm{n}=3$ \\
\hline recovery barley & $7(1)$ & $71(10)$ & $85(9)$ & $79(4)$ & $83(12)$ & $91(7)$ & $\mathrm{n}=3$ \\
\hline recovery rape & $25(15)$ & $66(16)$ & $82(11)$ & $81(9)$ & $85(13)$ & $73(8)$ & $\mathrm{n}=3$ \\
\hline recovery carrots -top & $12(9)$ & $65(6)$ & $71(10)$ & $76(4)$ & $74(9)$ & $71(12)$ & $\mathrm{n}=4$ \\
\hline recovery carrots - peel & $31(9)$ & $69(12)$ & $82(9)$ & $87(16)$ & $79(8)$ & 89 (18) & $\mathrm{n}=4$ \\
\hline recovery carrots - core & $6(3)$ & $72(15)$ & $57(11)$ & $75(9)$ & $65(7)$ & $92(11)$ & $\mathrm{n}=4$ \\
\hline recovery soil & $103(21)$ & $106(13)$ & $113(15)$ & $125(12)$ & $109(10)$ & $119(12)$ & $\mathrm{n}=4$ \\
\hline recovery pig manure & $73(10)$ & $83(9)$ & $93(8)$ & $89(16)$ & $68(15)$ & $106(6)$ & $\mathrm{n}=4$ \\
\hline recovery household compost & $92(26)$ & $82(19)$ & $93(8)$ & $89(17)$ & $64(22)$ & $81(11)$ & $\mathrm{n}=4$ \\
\hline recovery aerobic sludge & $89(20)$ & 87 (19) & $100(18)$ & $121(19)$ & $110(22)$ & $95(11)$ & $\mathrm{n}=4$ \\
\hline recovery anaerobic sludge & $90(2)$ & $88(3)$ & $107(15)$ & $123(25)$ & $102(21)$ & $104(9)$ & $\mathrm{n}=4$ \\
\hline
\end{tabular}

\footnotetext{
1) $\mu \mathrm{g} \mathrm{kg}^{-1}$ wet weight ${ }^{2)} \mathrm{ng}$ per $4 \mathrm{ml}$ final volume; day-by-day results

3) calculated from method blanks ${ }^{4)}$ method blanks $=0$; detection limit calculated from instrument detection limit
} 
plant or soil sample was analysed. Detection limits were obtained by analysing blank samples. Recoveries and repeatabilities were determined analysing samples with added known concentrations of phthalate esters for different matrices.

\section{Results and discussion}

Ultra Turrax treatment was a highly efficient tool to access organic compounds in the plant samples. The colourless residue after the homogenisation indicated extraction on the cellular level, as, apparently, all chlorophyll was removed from the cells. Although Ultra Turrax was also applied with good results for the homogenisation of sludge and soil samples, Ultra Turrax treatment cannot be the best choice for soil samples, as the function of the Turrax blade became reduced after a while due to the loss of sharpness of the blade, which made it inefficient for future plant samples.

Ion trap-tandem mass spectrometry was a suitable detection system for the analysis of phthalate esters. By searching only for the mother ion peak m/z 149 (m/z 163 for DMP) for identification, cleaning steps can be reduced to a minimum. The use of other detection system, such as electron capture detection (ECD) or flame ionisation detection (FID) requires extensive clean-up procedures to avoid misinterpretation due to co-eluting compounds [7]. Tandem mass spectrometry in the non-resonance mode required the optimisation of the CID excitation voltage and the RF storage level [22]. A CID voltage of $46 \mathrm{~V}$ was found to be the best for the selected mother ions (Fig 3).

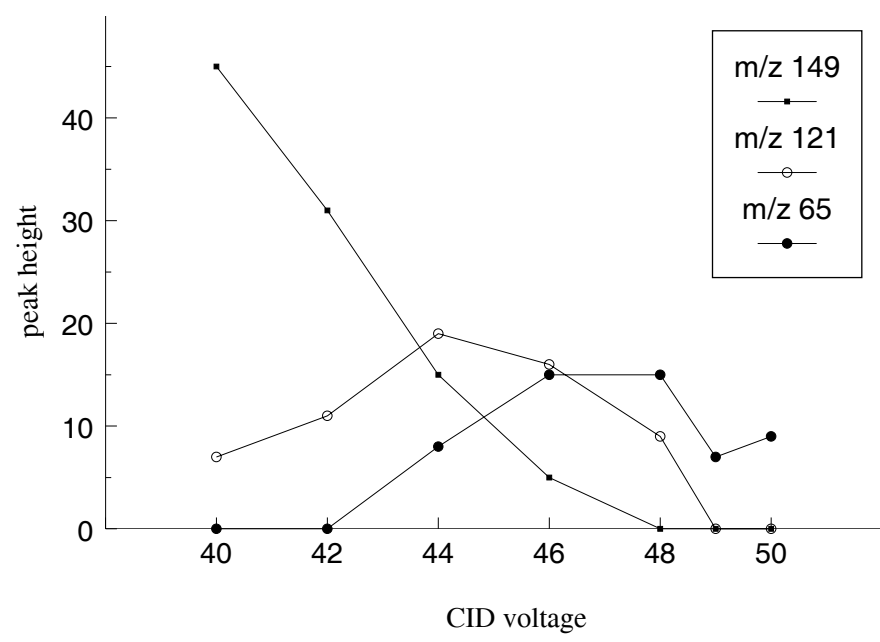

Fig 3. Voltage optimisation for the collusion-induced dissociation (CID) of phthalate esters with mother ion $\mathrm{m} / \mathrm{z} 149$

Table 3. Phthalate ester concentrations in different sample matrices. Values are $\mu \mathrm{g} \mathrm{kg}{ }^{-1}$ wet weight \pm relative standard variation $\mathrm{s}_{\mathrm{n}-1}$. Results not corrected for recoveries.

\begin{tabular}{c|c|c|c|c|c|c|c}
\hline matrix & DMP & DEP & DBP & BBP & DEHP & DOP & replicates \\
\hline barley & bdl & bdl & $12 \pm 4$ & bdl & bdl & $2 \pm 1$ & $\mathrm{n}=3$ \\
\hline rape & $2 \pm 1.4$ & $3 \pm 2.7$ & $5 \pm 1$ & bdl & bdl & bdl & $\mathrm{n}=3$ \\
\hline carrots -top & $1.3 \pm 0.1$ & bdl & $10 \pm 1$ & bdl & $31 \pm 10$ & bdl & $\mathrm{n}=3$ \\
\hline carrots - peel & $1 \pm 0.1$ & bdl & $23 \pm 4$ & $4 \pm 1.3$ & $84 \pm 31$ & $7 \pm 2$ & $\mathrm{n}=3$ \\
\hline carrots - core & bdl & bdl & $7 \pm 0.2$ & bdl & bdl & bdl & $\mathrm{n}=3$ \\
\hline soil & bdl & $9 \pm 0.5$ & $61 \pm 9$ & bdl & $182 \pm 41$ & bdl & $\mathrm{n}=3$ \\
\hline pig manure & bdl & $22 \pm 5$ & $149 \pm 46$ & bdl & $150 \pm 61$ & bdl & $\mathrm{n}=3$ \\
\hline household compost & bdl & $461 \pm 8$ & $286 \pm 36$ & bdl & $12204 \pm 708$ & $1235 \pm 145$ & $\mathrm{n}=3$ \\
\hline aerobic sludge & bdl & $1525 \pm 106$ & $1304 \pm 327$ & $1167 \pm 202$ & $12,183 \pm 1587$ & $1235 \pm 245$ & $\mathrm{n}=3$ \\
\hline anaerobic sludge & bdl & $906 \pm 29$ & $577 \pm 67$ & bdl & $20,438 \pm 2978$ & bdl & $\mathrm{n}=3$ \\
\hline
\end{tabular}

bdl = below detection limit 
With quantification of the single phthalate esters against individual calibration curves all the phthalates showed a narrow linear range. Dimethyl (DMP), diethyl (DEP) and di-n-butyl (DBP) phthalates had a linear range from 0 to $60 \mathrm{pg} \mu \mathrm{L}^{-1}$. Benzylbutyl (BBP), bis [2-ethylhexyl] (DEHP) and dioctyl (DOP) phthalate had a linear range from 1 to $100 \mathrm{pg} \mu \mathrm{L}^{-1}$. Thus, it was necessary to use suitable dilutions of the final extracts to keep within the linear ranges as required for robust quantification.

Method blanks and recoveries of different phthalate esters for various sample matrices are given in Table 2. For most of the phthalate esters, the recovery efficiency was more than $70 \%$ (range between 6 to $125 \%$ ). Some recoveries exceeded $100 \%$ probably due to point sources of the phthalate esters in the respective samples used for determining the recovery. The low recoveries obtained with the plant method for DMP and DEP is probably due to the loss of these most polar of the phthalate esters during the solid phase work up step of this version of the method. Therefore, the plant method should not be used for DMP and DEP.

The detection limits for most phthalates were in the range $1-10 \mu \mathrm{g} \mathrm{kg}^{-1}$ wet weight, but approaching $100 \mu \mathrm{g} \mathrm{kg}^{-1}$ wet weight for DEHP. This is probably due to the ubiquitous occurrence of this phthalate causing blank and sample contamination at this level. The detection limits are sufficiently low for the soil and waste samples, but improvement might be needed to quantify the concentrations in all plant samples for all phthalates (Table 3). Repeateabilities were generally in the range of 5 to $20 \%$ relative standard deviation and, thus, acceptable for analysis of compounds of known ubiquitous occurrence with a complex method.

The analysis of crops and organic waste products for phthalate esters showed the occurrence of DEHP in the highest concentrations especially in the organic waste products (Table 3). This finding is not astonishing as DEHP is one of the mostly used phthalate esters [23]. Due to its low volatility, stability and plasticizer properties DEHP is produced up to $20 \times 10^{6}$ tons per year [23]. Monitoring of DEHP in the environment is important as this compound is highly hydrophobic leading to increasing accumulation in the soil and plants. Furthermore, DEHP is suspected of being endocrine disrupters [24].

Due to increasing production of organic waste products and the need to find a sustainable and economical methods of waste disposal, the application in agriculture may be an efficient and low-cost method for disposal. However, this solution also involves risks regarding accumulation in the soil after sewage sludge application, followed by uptake into crops and a possible transfer to humans via the food chain [25]. The analysis of plants grown in the soil amended with organic wastes showed concentrations below $100 \mu \mathrm{g} \mathrm{kg}^{-1}$ wet weight for all phthalates, with the highest concentrations in carrot peel.

\section{Conclusion}

The use of Ultra Turrax extraction, solid phase extraction and ion trap tandem mass spectrometry detection gave a fast and reliable method for the investigation of different phthalate esters in a variety of waste and crop matrices. The detection limits were in the range of 1 to $10 \mu \mathrm{g} \mathrm{kg}^{-1}$ wet weight, except for DEHP that had a detection limit approaching $100 \mathrm{~kg}^{-1}$ wet weight. Repeatabilities were 5 to $20 \%$ relative standard deviation, and recoveries were from 6 to $100 \%$, depending on the compound analysed. However, except for the polar phthalate esters DMP and DEP, the recoveries were above $70 \%$. The analysis of plants grown in the soil amended with organic wastes showed concentrations below $100 \mu \mathrm{g} \mathrm{kg}^{-1}$ wet weight for all phthalates, with the highest concentrations in carrot peel. However, although phthalate esters are ubiquitous in the environment due to a widespread use and high release are the concentrations determined in the crops well below food contaminant maximum concentrations as defined by the European Commission, for example, for BBP $30 \mathrm{mg} \mathrm{kg}^{-1}$ food, for DEHP $1.5 \mathrm{mg} \mathrm{kg}^{-1}$ food, for DBP $0.3 \mathrm{mg} \mathrm{kg}^{-1}$ food [26].

\section{Acknowledgements}

We gratefully acknowledge the help of Ingelis Larson for laboratory assistant. The work was financed by grants from the Danish Environmental Protection Agency and the Danish Strategic Environmental Research Program. FL gratefully acknowledge a fellowship of the Hanse Institute for Advanced Studies, Germany. This publication contributes to COST Action 859 on Phytotechnologies to promote sustainable land use and improve food safety. COST 859 is financed by the European Science Foundation (ESF).

\section{References}

1. SMITH, S. R. Agricultural recycling of sewage sludge in the environment. CAB International, Wallingford, 1996.

2. STAPLES, C.; PETERSON, D.; PARKERTON, T.; ADAMS, W. The environmental fate of phthalate esters: a literature review. Chemosphere, 1997, 35, p 667-749.

3. RITSEMA, R.; COFINO, W. P.; FRINTROP, P. C. M.; BRINKMAN, U. A. T. Trace level analysis of phthalate esters. Chemosphere, 1989, 18, p 2161-2175.

4. BROWN, D.; THOMPSON, R. S.; STEWART, K. M.; CROUDACE, C. P.; GILLINGS, E. The effect of phthalate ester plasticizers on the emergence of the midge (Chironomus riparius) from treated sediments. Chemosphere, 1996, 32, p 2177-2187.

5. JIANLONG, W.; PING, L.; HANCHANG, S.; YI, Q. Kinetics of biodegradation of phthalic acid esters in continuous culture system. Chemosphere, 1998, 37, p 257-264.

6. WAMS, T. J. Diethylhexylphthalates as an environmental contaminant - a review. Science of the Total Environment, 1987, 66, p 1-16.

7. FURTMANN, K. Phthalates in surface water: a method for routine trace level analysis. Fresenius Journal of Analytical Chemistry, 1994, 348, p 291-296.

8. RAY, L. E.; MURRAY, H. E.; GIAM, C. S. Organic pollutants in marine samples from Portland, Maine. Chemosphere, 1983, 12, p 1031-1038.

9. HOLADOVÁ, K.; HAJSLOVÁ, J. A comparison of different ways of sample preparation for the determination of phthalic acid esters in water and plant matrices. International Journal of Environmental Analytical Chemistry, 1995, 59, p 43-57. 
10. MÜLLER, J.; KÖRDEL, W. Occurrence and fate of phthalates in soil and plants. Science of the Total Environment, 1993, Supplement, p 431-437.

11. BRUMLEY, W. C.; SHAFTER, E. M.; TILLANDER, P. E. Determination of phthalates in water and soil by mass spectrometry under chemical ionization conditions with isobutene as a reagent gas. Journal of AOAC International, 1994, 77, p 1230-1236.

12. JENG, W. Phthalate esters in marine sediments around Taiwan. Acta Oceanographica Taiwanica, 1986, 17, p 6188.

13. DORNEY, J. R.; WEBER, J. B.; OVERCASH, M. R.; STREK, H. J. Plant uptake and soil retention of phthalic acid applied to Norfolk sandy loam. Journal of Agricultural and Food Chemistry, 1985, 33, p 398-403.

14. SCHMITZER, J. L.; SCHEUNERT, I.; KORTE, F. Fate of bis (2-ethylhexyl)[14C] phthalate in laboratory and outdoor soil-plant systems. Journal of Agricultural and Food Chemistry, 1988, 36, p 210-215.

15. LOPEZ-AVILA, V.; MILANES, J.; BECKERT, W. F. Single Laboratory evaluation of method 8060 for the determination of phthalates in environmental samples. Journal Association of Official Analytical Chemists, 1991, 74, p 793-808.

16. BABIC, S.; PETROVIC, M.; KASTELAN-MACAN, M. Ultrasonic extraction of pesticides from soil. Journal of Chromatography A, 1998, 823, p 3-9.

17. HEEMKEN, O. P.; THEOBALD, N.; WENCLAWIAK, B. W. Comparison of ASE and SFE with Soxhlet, Sonication, and Methanolic Saponification Extractions for the Determination of Organic Micropollutants in Marine Particulate Matter. Analytical Chemistry, 1997, 69, p 21712180.

18. WAGROWSKI, D. M.; HITES, R. A. Polycyclic aromatic hydrocarbons accumulation in urban, suburban, and rural vegetation. Environmental Science \& Technology, 1997, 31, p 279-282.

19. WILD, S. R.; BERROW, M. L.; MCGRATH, S. P.; JONES, K. C. Polynuclear aromatic hydrocarbons in crops from long-term field experiments amended with sewage sludge. Environmental Pollution, 1992, 76, p $25-$ 32.
20. SHEA, P .J.; WEBER, J. B.; OVERCASH, M. R. Uptake and phytotoxicity of di-n-butyl phthalate in corn (Zea mays). Bulletin of Environmental Contamination and Toxicology, 1982, 29, p 153-158.

21. GRØN, C.; LATURNUS, F.; MORTENSEN, G. K.; EGSGAARD, H.; BENNETZEN, S.; SAMSØEPETERSEN, L.; AMBUS, P.; JENSEN, E. J. Plant uptake of LAS and DEHP from sludge-amended soil. In Lipnick, R.; Muir, D.; Hermens, J. (Eds). Persistent Bioaccumulative Toxic Chemicals: Fate and Exposure. ACS Symp. Ser. 772, American Chemical Society, Washington D. C., 2000, p 99-111.

22. STEEN, R. J. C. A.; FRERIKS, I. L.; COFINO, W. P.; BRINKMANN, U. A. T. Large-volume injection in gas chromatography-ion trap tandem mass spectrometry for the determination of pesticides in the marine environment at low ng/l lever. Analytica Chimica Acta, 1997, 353, p 153-163.

23. BAGO, B.; MARTIN, Y.; MEJIA, G.; BROTOPUIG, F.; DIAZ-FERRERO, J.; AGUT, M.; COMELLAS, L. Di-(2ethylhexyl) phthalate in sewage sludge and post-treated sludge: Quantitative determination by HRGC-MS and mass spectral characterization. Chemosphere, 2005, 59, p 1191-1195.

24. WARING, R. H.; HARRIS, R. M. Endocrine disrupters: A human risk? Molecular and Cellular Endocrinology, 2005, 244, p 2-9.

25. LATURNUS, F.; VON ARNOLD, K.; GRØN, C. Organic Contaminants from Sewage Sludge Applied to Agricultural Soils - False Alarm Regarding Possible Problems for Food Safety? ESPR - Environmental Science and Pollution Research, 2007, 14, p 53-60.

26. Commission Directive 2007/19/EC of 2 April 2007 amending Directive 2002/72/EC relating to plastic materials and articles intended to come into contact with food and Council Directive 85/572/EEC laying down the list of simulants to be used for testing migration of constituents of plastic materials and articles intended to come into contact with foodstuffs.

\section{ORGANINIUU ATLIEKUৃ PRODUKTAI ŽEMĖS ŪKYJE - ATLIEKU巳 SUDEDAMOSIOS DALIES PHTHALE ESTERIU SISTEMOJE DIRVOŽEMIS-PASĖLIAI MONITORINGAS CHROMATOGRAFIJOS IR JONŲ PORŲ IŠDĖSTYTOS MASĖS SPEKTROMETRIJOS BŪDU}

\section{F. Laturnus and Ch. Grøn}

\section{Santrauka}

Aprašytas metodas yra skirtas phthalate esterių monitoringui organinių atliekų produktuose, žemės ūkio dirvožemyje ir pasèliuose. Junginiams nuo bandinio terpès atskirti buvo taikyta tirpiklio ekstrakcija, Ultra Turrax homogenizacija ir sonifikacija. Kietosios fazès ekstrakcija buvo taikyta valymui, o identifikacijai - dujų chromatografija su išdèstytos masès spektrometru. Šiuo metodu šešiu rūšių phthalate esteriai buvo nustatyti i̇vairiose terpése. Identifikacijos ribos buvo $1-10 \mu \mathrm{g} \mathrm{kg}^{-1}$ šlapiosios masès, išskyrus $D E H P$ atveju, kurio nustatymo riba artima $100 \mu \mathrm{g} \mathrm{kg}^{-1}$ šlapiosios masės. Pakartojimai skyrėsi nuo reliatyvaus standartinio 5-20\%. Atkūrimas buvo 6-100\%, atsižvelgiant i junginių suskaidymą. Tačiau, išskyrus poliniu phthalate $D M P$ ir $D E P$ atvejus, atkūrimas buvo $70 \%$. Metodo pagristumas buvo pademonstruotas, atliekant phthalate tyrinèjimus miežiuose, rapsuose, morkose, žemès ūkio dirvožemyje, aerobiniame ir anaerobiniame dumble, namų ūkio komposte ir kiaulių mèšle.

Reikšminiai žodžiai: phthalate esteriai, nutekamujų vandenų dumblas, išdèstytos masès spektrometras, jonų poros, žemės ūkis. 
ПРОДУКТЫ ОРГАНИЧЕСКИХ ОТХОДОВ В СЕЛЬСКОМ ХОЗЯЙСТВЕ. МОНИТОРИНГ СОСТАВНОЙ ЧАСТИ ОТХОДОВ - ЭФИРА РНТНАLAТЕ В СИСТЕМЕ ПОЧВА-ПОСЕВЫ СПОСОБОМ ХРОМАТОГРАФИИ И СПЕКТРОМЕТРИИ РАЗЛОЖЕННОЙ МАССЫ ПОР ИОНОВ

\author{
Ф. Латурнус, К. Грен \\ Р ез ю м е
}

Описанный метод предназначен для мониторинга эфира Phthalate в органических отходах продуктов сельского хозяйства, почве и посевах. Для отделения соединений от опытной среды была применена экстракция растворителя, гомогенизация и сонификация Ultra Turrax. Экстракция твердой фазы была применена для очистки, а для идентификации - газовая хроматография со спектрометром разложенной массы. С помощью этого метода эфир Phthalate шести сортов был обнаружен в разных средах. Граница идентификации составляла $1-10 \mu \kappa^{-1} \Gamma^{-1}$ мокрого веса, кроме случая DEHP, граница которого близка к $100 \mu \kappa_{\text {кг }}^{-1}$ мокрого веса. Повторы отклонялись от релятивного стандарта на 5-20\%. Восстановление составило 6-100\% с учетом дробления соединений. Однако, кроме случаев полярных Phthalate DMP и DEP, восстановление составляло $70 \%$. Обоснованность метода была продемонстрирована исследованием эфира Phthalate в ячмене, рапсе, моркови, сельскохозяйственной почве, аэробинамическом и анаэробинамическом иле, компосте из бытовых отходов и свином навозе.

Ключевые слова: эфир Phthalate, ил сточных вод, спектрометр разложенной массы, поры ионов, сельское хозяйство.

Laturnus FRANK. Dr of Natural Sciences (marine and analytical chemistry), University of Bremen, 1993. Dr Habil of Natural Sciences (environmental chemistry), University of Copenhagen, 2003. Publications: author of 40 international scientific publications. Honorary awards and membership: research fellow, Hanse Institute for Advanced Studies, Delmenhorst, Germany; Management Committee member and STSM Evaluation Committee member of EU COST Action 859; member of the American Geophysical Union (AGU). Research interests: phytoremediation; natural halogen cycle; effect of climate changes on the environment.

Grøn CHRISTIAN. Dr of Natural Sciences (organic groundwater chemistry), Technical University of Copenhagen, 1989. Publications: author of 38 international scientific publications. Honorary awards and membership: member of the Society of Environmental Toxicology and Chemistry, the International Water Association (IWA), the Society for Environmental Engineering (IDAmiljø), the Society of Danish Engineers, the Biowaste and Soil working groups of the Danish Waste Association (DAKOFA), the Bioavailability Research Group Europe, the EURACHEM Working Group on Uncertainty from Sampling; member of the Editorial committees for Journal of Environmental Science and Health, Part A and the Danish journal Water and Soil (vand \& jord). Research interests: occurrence and fate of contaminants in water, soil, air, waste and biota; treatment technologies for water, soil and waste; humic acids in the environment. 